\title{
Decrease of $\gamma$-aminobutyric acid and zinc ions in the islet periportal circulation stimulates glucagon secretion during hypoglycemia
}

\author{
TINGTING YU ${ }^{1,2^{*}}$, ZHONGHUA JIANG ${ }^{2 *}$, LI LIU ${ }^{1}$ and ZHINING FAN ${ }^{1}$ \\ ${ }^{1}$ Department of Digestive Medicine, Institute of Digestive Endoscopy, \\ The First Affiliated Hospital of Nanjing Medical University, Nanjing, Jiangsu 210000; \\ ${ }^{2}$ Department of Gastroenterology, The First People's Hospital of Yancheng, Yancheng, Jiangsu 224000, P.R. China
}

Received November 30, 2016; Accepted July 7, 2017

DOI: $10.3892 /$ etm.2017.5670

\begin{abstract}
The present study assessed the effects of $\gamma$-aminobutyric acid (GABA) from $\beta$-cells on glucose levels and glucagon secretion, and identified channels via which glucagon secretion is initiated. An in vivo experiment was performed containing three groups: Intrapancreatic artery infusion of GABA alone, GABA plus insulin or insulin alone in rats with diabetes. Rats infused with GABA and insulin were also subdivided in groups receiving additional infusion of $\mathrm{K}^{+}$-channel activator diazoxide (DIA), $\mathrm{K}^{+}$-channel blocker tolbutamide (TLB) and calcium channel blocker nifedipine (NIF). In the hypoglycemic state, termination of infusion of insulin and insulin plus GABA resulted in signaling to the $\alpha$-cells to secrete glycogen, while that of GABA alone did not. However, intrapancreatic artery infusion of $\mathrm{K}^{+}$-channel activator DIA, $\mathrm{K}^{+}$-channel blocker TLB or calcium channel blocker NIF in addition to GABA and insulin had no effect on glucagon secretion. In conclusion, if the delivery of insulin or GABA plus insulin in rats with hypoglycemia is terminated, $\beta$-cells are stimulated and signal the $\alpha$-cells to secrete glucagon. Thus, the detection of a sudden decrease in zinc levels by $\beta$-cells as well as a decrease in GABA in the periportal circulation induces signaling to $\alpha$-cells to stimulate them to secrete glucagon.
\end{abstract}

Correspondence to: Dr Zhining Fan, Department of Digestive Medicine, Institute of Digestive Endoscopy, The First Affiliated Hospital of Nanjing Medical University, 300 Guangzhou Road, Nanjing, Jiangsu 210000, P.R. China

E-mail: fanzhining@hotmail.com

*Contributed equally

Key words: $\gamma$-aminobutyric acid, GABA, insulin, hypoglycemia, diabetes, zinc ions, glucagon

\section{Introduction}

Treatment for patients with type 1 or advanced type 2 diabetes by use of exogenous insulin places them at high risk for hypoglycemia. The physiological response to hypoglycemia involves multiple intrinsic defense mechanisms, which consists of input signals sent by the central nervous system and release of epinephrine, glucagon, cortisol and growth hormone. A chief mechanism among these is the increase in glucagon secretion. In patients with diabetes, the counter-regulatory glucagon response is severely compromised. Numerous in vitro and in vivo studies have proposed that insulin, $\mathrm{Zn}^{2+}, \gamma$-aminobutyric acid (GABA) and somatostatin exerts a paracrine control on glucagon secretion under certain conditions $(1,2)$.

Within the islets, the regulation of glucagon secretion by glucose and paracrine factors (i.e., $\beta$-cell secretory products) is mediated by electrical machinery comprising a variety of ion channels that determine the depolarization or hyperpolarization of $\alpha$-cells (3). The intra-islet insulin hypothesis holds that upon decreasing insulin secretion by $\beta$-cells, they may send a signal to $\alpha$-cells that contributes to the release of glucagon. Another hypothesis infers that glucagon secretion is inhibited by zinc ions due to their effects on adenosine triphosphate (ATP)-sensitive $\mathrm{K}^{+}$-channels of $\alpha$-cells (4). In vivo studies have demonstrated that if insulin or zinc ion infusion into the pancreatic artery is performed, while animals are made hypoglycemic by an insulin infusion through the jugular vein, following the end of the infusion glucagon secretion is stimulated in animals with diabetes, but not in animals without diabetes (4-6).

GABA serves as an inhibitor in the central nervous system and at high concentration, it has a marked effect on the endocrine pancreas (7-9). The former studies have verified that in animals with repeated hypoglycemia, impaired glucagon and epinephrine responses are associated with more GABAergic tone in the ventromedial hypothalamus. In previous studies, activation of the $\mathrm{GABA}_{\mathrm{A}}$ receptor $\left(\mathrm{GABA}_{\mathrm{A}} \mathrm{R}\right)$ by alprazolam on day 1 blunted autonomic nervous system (ANS) and neuroendocrine responses; as a result $\mathrm{GABA}_{\mathrm{A}} \mathrm{R}$ expression decreased on day 2 . However, these results did not fully prove whether the prior activation had any negative impact on releasing glucagon 
through directly influencing pancreatic islets or affecting neural pathways (probably ANS) (10). However, certain other studies demonstrated that exogenous GABA did not cause the release of glucagon from the isolated dog pancreas. In this species, GABA did not affect the concentration of glucagon in vivo, regardless of whether administration was oral or by intravenous injection $(11,12)$. However, different findings were obtained in human patients, as the circulating levels of glucagon increased with oral GABA $(13,14)$. By contrast, in isolated mouse islets cultured with $0 \mathrm{mmol} / \mathrm{l}$ glucose, exogenous GABA inhibited the secretion of glucagon (15). However, limited data are available on the GABAergic tone within the islets from the hypoglycemic rats. Therefore, it has remained to be determined whether GABA from $\beta$-cells promotes the effects of glucose on glucagon secretion.

In order to verify this hypothesis, the present study performed an in vivo experiment comprising three study groups: Intrapancreatic artery infusion of GABA alone, GABA plus insulin or insulin alone in Wistar rats with diabetes.

To investigate what channels are involved in the initiation of glucagon secretion following termination of insulin plus GABA infusion, the present study also performed diazoxide (DIA), tolbutamide (TLB) and nifedipine (NIF) intrapancreatic artery infusions plus GABA and insulin.

\section{Materials and methods}

Experimental animals. Approval of the animal experiments was obtained from the Animal Care and Use Committee of Nanjing Medical University (Nanjing, China). All procedures were performed with an approved Home Office project license and in accordance with the Animals (Scientific Procedures) Act 1986 (UK; amended 2013). All sections of the present study are in accordance with the Animal Research: Reporting Of In Vivo Experiments guidelines for reporting animal research.

A total of 30 male Wistar rats (weight, 350-400 g; age, 3-4 month old) were obtained from the animal center of Qing long Shan (Nanjing, China). Animals were housed at $23^{\circ} \mathrm{C}$ with a 12-h light/dark cycle, a relative humidity of $40-70 \%$, and were provided food and water ad libitum.

Diabetes was induced by intraperitoneal injection of $50 \mathrm{mg} / \mathrm{kg}$ streptozotocin (STZ; Sigma-Aldrich; Merck KGaA, Darmstadt, Germany) dissolved in sodium citrate buffer. At one and two days after injecting STZ, blood glucose was measured. The rats were identified as diabetic if the results of two sequential measurements were $>350 \mathrm{mg} / \mathrm{dl}$. The animals that had not become diabetic were injected with STZ for a second time. Animals were kept for 2 weeks until they weighed 300-350 g, so that they could be used for the experiments.

Glucagon response assessment. At 2 weeks after the establishment of diabetes by STZ injection, the rats were assessed for their complete ability to respond to hypoglycemia as in the very beginning. Diabetic rats were fasted overnight, anesthetized and given an insulin (Eli Lilly and Company, Indianapolis, IN, USA) infusion ( 0.5 units $/ \mathrm{ml}$ at $50 \mu \mathrm{l} / \mathrm{min})$ into the jugular vein so as to cause a hypoglycemic state. The dynamic data of blood glucose, C-peptide and glucagon were collected at the time-points of 0, 30, 60 and 90 min following termination of the infusion. Blood glucose levels were measured within 2 min of sample collection. Finally, the jugular catheter was removed and the incision was closed.

Surgical procedure. Isoflurane (2\%) was used to anesthetize the non-fasted rats on the experimental day of the intrapancreatic artery infusions. The upper abdomen was opened through a $3 \mathrm{~cm}$-long vertical incision commencing from the xiphoid process. A 25-gauge needle was used to puncture the isolated and ligated hepatic artery, into which a microcannula (0.008 mm inner diameter; Biotime, Inc., Alameda, CA, USA) was inserted in a higher position for retrograde conduction to the start of the pancreatic artery, which was ligated over the cannula. The location of the cannula tip was the bottom of the superior pancreatic duodenal artery, which carried the infusion fluid through the microcannula and had no negative impact on supplying blood from the celiac artery to the pancreatic artery. The right jugular vein was cannulated by heparin-filled (500 units $/ \mathrm{ml}$ ) polyethylene 50 tubing (BD Biosciences, Franklin Lakes, NJ, USA), which was placed superior to the vena cava. The function of the cannula was to help infuse intravenous insulin and collect blood samples. In order not let the opened abdomen dry out due to surgery, it was perfused with warm saline and the surface was covered in foil.

Once the defective glucagon response in the diabetic animals had been established, animals were considered to have finished the glucagon response assessment. After 2 weeks of recovery, the animals were anesthetized and rested for $30 \mathrm{~min}$. In order to lower blood glucose to $100 \mathrm{mg} / \mathrm{dl}$, insulin $(0.5$ units $/ \mathrm{ml}$ at 50 units $/ \mathrm{min})$ was infused into the jugular vein. After this procedure, a basal blood sample was collected, followed by infusion of the following solutions into the superior pancreaticoduodenal artery: GABA (50 $\mu \mathrm{mol} / \mathrm{l})$, TLB $(50 \mu \mathrm{mol} / \mathrm{l})$, DIA $(50 \mu \mathrm{mol} / \mathrm{l}), \mathrm{NIF}(1 \mu \mathrm{mol} / \mathrm{l})$ and insulin (1.5 units/ml). Glucagon levels in hypoglycemic rats were not significantly different in rats with zinc-free insulin infusion compared with rats without intrapancreatic artery infusion; therefore, the control group $(n=5)$ was infused with zinc-free insulin infusion to explain the role of zinc. Then the animals were split into three groups and infused with GABA or Insulin or GABA and insulin (n=5/group). Following that another group of animals were split into three groups and infused with GABA, insulin and TLB or GABA or NIF ( $n=3 /$ group). A total of 1 rat without intrapancreatic artery infusion was used as blank control rat as a reference for the control group. The standard of the concentrations of these solutions was set according to the studies of Franklin et al (16) and Mehanna (17). Another blood sample was collected after $10 \mathrm{~min}$. As soon as the blood glucose was decreased to $<60 \mathrm{mg} / \mathrm{dl}$, the infusions to the pancreatic artery were terminated and blood samples were collected at the time-points of 0, 15, 30, 60 and $90 \mathrm{~min}$.

Assays. The aforementioned blood samples $(0.3 \mathrm{ml}$ from the jugular vein at each time points) were stored in 1,000 IU/ml Trasylol solution in heparin-coated ice-chilled tubes to prevent glucagon degradation. As for the measurement, the Roche Accucheck glucometer (Roche, Basel, Switzerland) was used to measure plasma glucose. Furthermore, rat C-peptide (cat. 

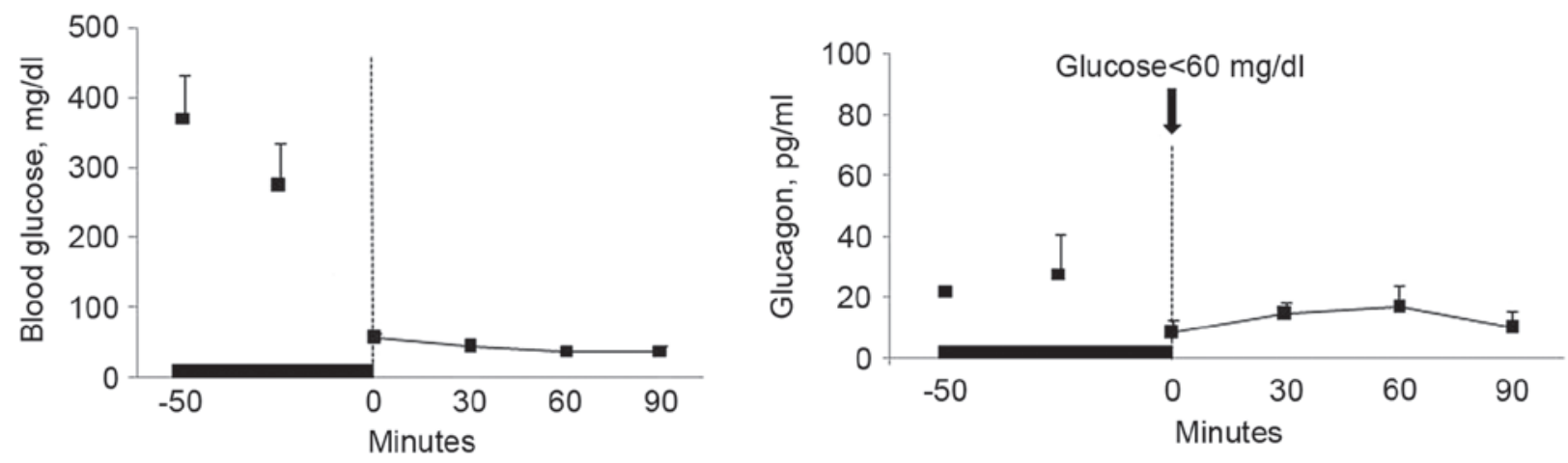

Figure 1. Zinc-free insulin infusion. Blood glucose and glucagon levels of diabetic rats with hypoglycemia in three stages: Prior to, during and after intrapancreatic artery infusion of zinc-free insulin ( $1.5 \mathrm{units} / \mathrm{ml})(\mathrm{n}=5$ per group). The time-point of termination of the infusions is set as 0 and is indicated by the vertical dashed line.
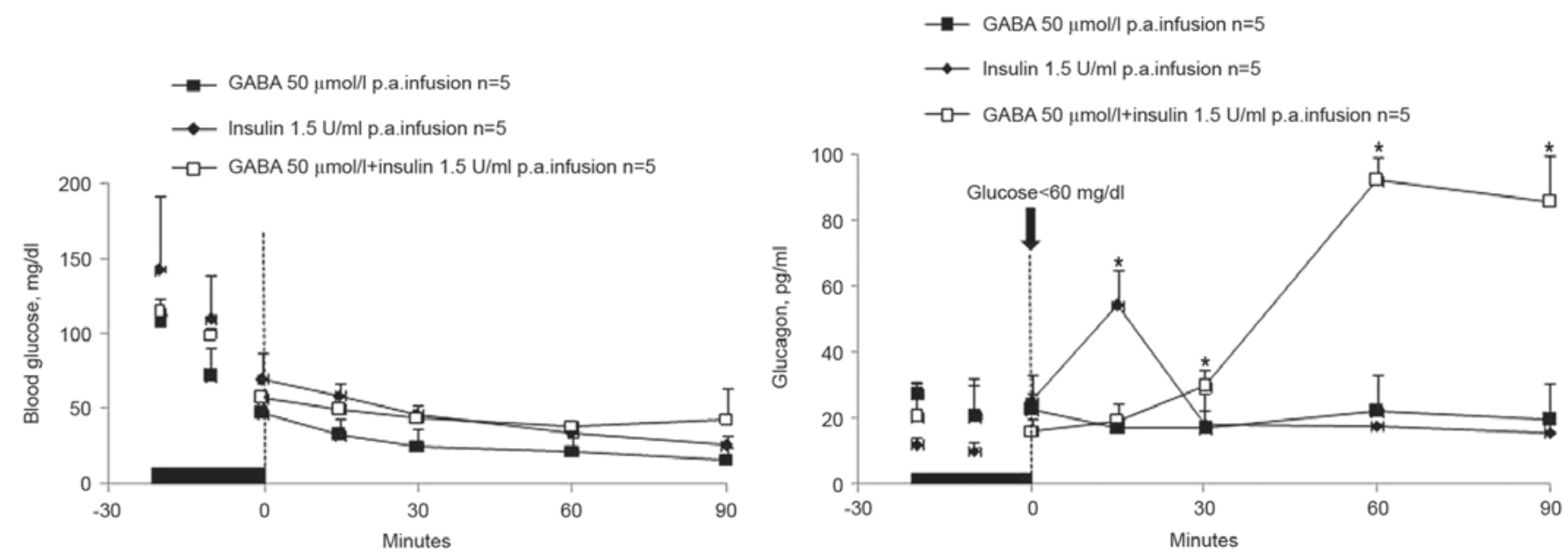

Figure 2. Infusion of insulin, GABA or GABA plus insulin. Blood glucose and glucagon levels of diabetic rats with hypoglycemia in three stages: Prior to, during and after intrapancreatic artery infusion of GABA $(50 \mu \mathrm{mol} / \mathrm{l})$, GABA $(50 \mu \mathrm{mol} / \mathrm{l})+$ insulin $(1.5 \mathrm{U} / \mathrm{ml})$ and insulin $(1.5 \mathrm{U} / \mathrm{ml})(\mathrm{n}=5 \mathrm{per}$ group). The time-point of termination of the infusions is set as 0 and is indicated by the vertical dashed line. In all stages, the nadirs of glucose were $<60 \mathrm{mg} / \mathrm{dl}$, while C-peptide was not responsive and difficult to detect. ${ }^{*} \mathrm{P}<0.05$ vs. the GABA group. GABA, $\gamma$-aminobutyric acid.

no. K4757-100) and glucagon (cat. no. K4756-100) (both Biovision, Inc., Milpitas, CA, USA) enzyme immunoassay kits were used to measure plasma levels of glucagon and C-peptide.

Statistical analysis. Data were presented as mean \pm standard and statistically analyzed using either an unpaired Student's t-test or a one-way analysis of variance with Dunn's post hoc test. These tests were conducted by GraphPad Prism analytical software (version 5; GraphPad Software, Inc., La Jolla, CA, USA). $\mathrm{P}<0.05$ was considered to indicate a statistically significant difference.

\section{Results}

GABA plus zinc-containing insulin stimulate $\alpha$-cells to secrete glucagon in rats with hypoglycemia. The results demonstrated that termination of infusion of zinc-free insulin into the pancreatic artery had no marked effect on glucagon levels in the blood of hypoglycemic rats (Fig. 1). GABA infusion also had no marked effect on glucagon levels in the blood of hypoglycemic rats (Fig. 2). Although glucagon levels in the insulin group peaked 15 min after

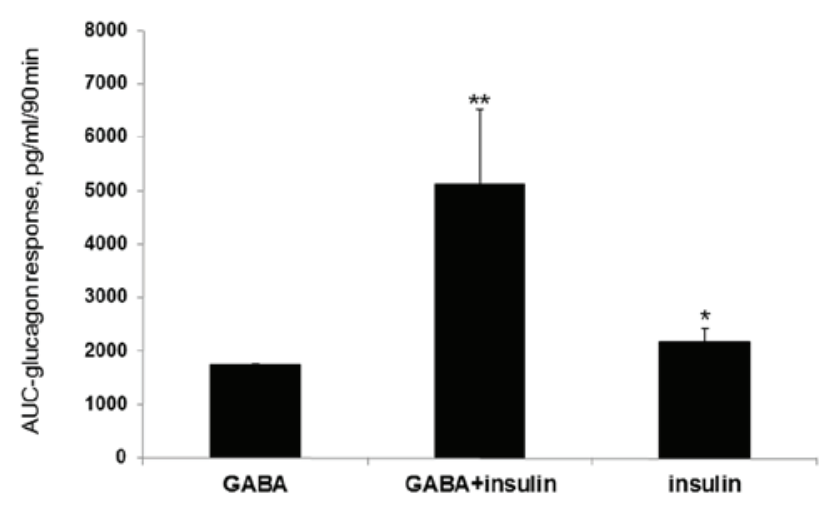

Figure 3. AUCs for the glucagon responses in the three different experimental groups. ${ }^{*} \mathrm{P}<0.05,{ }^{* *} \mathrm{P}<0.02$ vs. the GABA group. AUC, area under curve; GABA, $\gamma$-aminobutyric acid.

infusion the overall level was lower that that of the GABA plus insulin group. Of note, termination of the GABA plus insulin infusion into the pancreatic artery promoted glucagon secretion in rats with hypoglycemia, which was more effective than termination of the infusion of insulin 

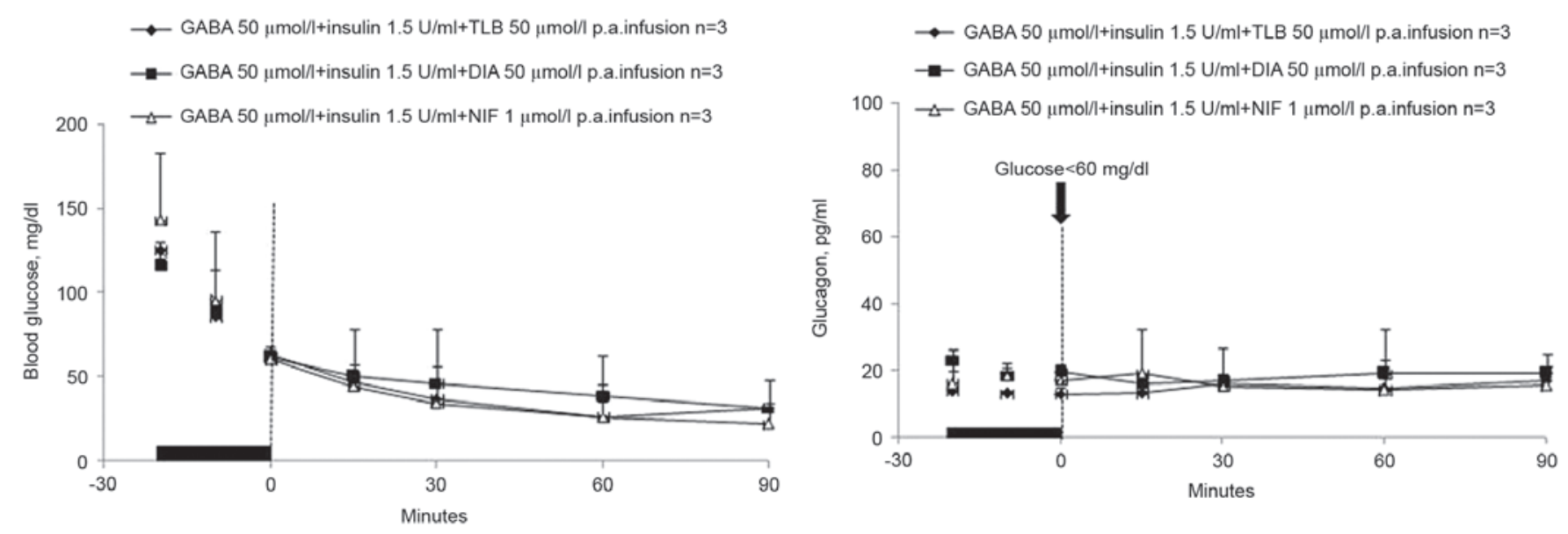

Figure 4. DIA, TLB or NIF infusions. The concentration levels of blood glucose and glucagon of diabetic rats in hypoglycemia in three stages: Prior to, during and after intrapancreatic artery infusions of GABA $(50 \mu \mathrm{mol} / \mathrm{l})+$ insulin $(1.5 \mathrm{U} / \mathrm{ml})+\mathrm{TLB}(50 \mu \mathrm{mol} / \mathrm{l})$, GABA $(50 \mu \mathrm{mol} / \mathrm{l})+\mathrm{insulin}(1.5 \mathrm{U} / \mathrm{ml})+\mathrm{DIA}$ $(50 \mu \mathrm{mol} / \mathrm{l}), \mathrm{GABA}(50 \mu \mathrm{mol} / \mathrm{l})+$ insulin $(1.5 \mathrm{U} / \mathrm{ml})+\mathrm{NIF}(1 \mu \mathrm{mol} / \mathrm{l})(\mathrm{n}=3$ per group). The time-point of termination of the infusions is set as 0 and is indicated by the vertical dashed line. In all stages, the nadirs of glucose were $<60 \mathrm{mg} / \mathrm{dl}$, while C-peptide was not detectable. Glucagon levels of three groups were compared with the GABA group. GABA, $\gamma$-aminobutyric acid; DIA, diazoxide; TLB, tolbutamide; NIF, nifedipine.

alone $(\mathrm{AUC}=2,161 \pm 260 \mathrm{pg} / \mathrm{ml}$ in a $90 \mathrm{~min}$ time span; $\mathrm{P}<0.02$; Figs. 2 and 3). In the GABA plus insulin group, a significant glucagon response (AUC $=5,120 \pm 1395 \mathrm{pg} / \mathrm{ml}$ in a $90 \mathrm{~min}$ time span; $\mathrm{P}<0.02$; Figs. 2 and 3) was observed compared with the GABA alone group (AUC $=1,749 \pm 6.87 \mathrm{pg} / \mathrm{ml}$ in a $90 \mathrm{~min}$ time span; $\mathrm{P}<0.02$; Figs. 2 and 3). However, C-peptide levels did not respond to the termination of the pancreatic arterial infusions of zinc-free insulin or GABA and were hard to measure (results not shown).

Ion channel activator and blockers do not affect glucagon secretion when infused with GABA and insulin. Furthermore, DIA, TLB or NIF intrapancreatic artery infusions plus GABA and insulin had no significant effect on glucagon secretion (Fig. 4). These results demonstrated that termination of delivery of insulin or GABA plus zinc-containing insulin, but not of GABA alone, induced $\beta$-cells to send a signal to the $\alpha$-cells, which stimulated the latter to secrete glucagon in rats with hypoglycemia. Decrements of GABA plus zinc-containing insulin caused a greater activation signal than those of zinc-containing insulin or GABA alone.

\section{Discussion}

Various intra-islet insulin hypotheses suggested that glucagon secretion was suppressed by insulin from $\beta$-cells. On the contrary, in the hypoglycemic state, the marked attenuation of insulin results in signaling to $\alpha$-cells to promote glucagon secretion (18-20).

The present study aimed to assess whether GABA had any effect on the glucagon secretion after termination of its infusion with or without insulin. The in vivo experiment on Wistar rats with streptozotocin-induced diabetes demonstrated that in the hypoglycemic state, termination of infusion with zinc-containing insulin and zinc-containing insulin plus GABA but not GABA alone stimulated $\alpha$-cells to secrete glucagon. Termination of infusion of GABA plus zinc-containing insulin resulted in a greater activation signal than that of zinc-containing insulin alone.
At the molecular level, insulin activates intra-islet insulin signaling involving the activation of the phosphoinositide-3 kinase/Akt signaling pathway, which induces subsequent phosphorylation of the $\beta$-subunit of $\mathrm{GABA}_{\mathrm{A}} \mathrm{R}$ and the translocation of receptors from the intracellular pool to the plasma membrane. The resulting increase in the $\alpha$-cell surface expression of $\mathrm{GABA}_{\mathrm{A}} \mathrm{Rs}$ leads to $\alpha$-cell membrane hyperpolarization and the suppression of glucagon secretion (21). As GABA is constantly released from $\beta$-cells (22), the increased number of $\mathrm{GABA}_{\mathrm{A}} \mathrm{Rs}$ at the cell surface increases the efficacy of the receptor-mediated inhibitory currents $(\mathrm{Cl} 2)$ and membrane hyperpolarization occurs. In turn, membrane hyperpolarization shuts down voltage-dependent $\mathrm{Ca}^{2+}$ channels (23), resulting in the inhibition of cell exocytosis and glucagon release. Göpel et al (24) demonstrated that in $\mathrm{K}^{+} \mathrm{ATP}$ channels, zinc activation occurred, which promoted $\beta$-cell hyperpolarization and had a negative impact on the influx of cytosolic $\mathrm{Ca}^{2+}$, which has an important role in secreting glucagon. Slucca et al (25) suggested that during hypoglycemia, $\beta$-cells actually stop releasing zinc-insulin. The lack of zinc effects the closure of $\alpha$-cell $\mathrm{K}^{+} \mathrm{ATP}$ channels. This in turn leads to depolarization, which leads to the opening of the voltage-dependent calcium channels and entry of calcium, which causes glucagon exocytosis. It many therefore be inferred that upon the interaction of $\beta$-cells with insulin, they release GABA and $\mathrm{Zn}^{2+}$, respectively. Under hypoglycemia, $\beta$-cells cease to cause the release of zinc, which leads to closure of the $\alpha$-cell $\mathrm{K}^{+} \mathrm{ATP}$ channels. Furthermore, a decrement in GABA secretion decreases the translocation of $\mathrm{GABA}_{\mathrm{A}} \mathrm{R}$ to the plasma membrane, which then decreases the efficacy of receptor-mediated $\mathrm{Cl} 2$. As a result, the decrease of $\mathrm{K}^{+} \mathrm{ATP}$ and $\mathrm{Cl}^{-}$currents causes depolarization, leading to the opening of calcium channels to allow for calcium entry and glucagon exocytosis. The fact that GABA, independent of insulin, cannot have any insulin-like effects is well appreciated.

However, the finding of the present study that DIA, TLB or NIF infusions plus GABA and insulin had no effect on glucagon secretion cannot be explained. Thus, further study is required to elucidate the effects of $\mathrm{K}^{+}$-channel activator DIA, 
$\mathrm{K}^{+}$-channel blocker TLB or calcium channel blocker NIF on the switch-off signal.

In conclusion, the present study suggested that during hypoglycemia, $\alpha$-cells receiving a signal from $\beta$-cells secrete glucagon. Based on these findings, $\alpha$-cell-produced glucagon was detected as a result of a sudden decrease in zinc-bearing insulin and GABA in the periportal circulation. The decrease of the concentration of zinc-containing insulin and GABA, but not insulin or GABA alone, may have reduced the $\mathrm{K}^{+} \mathrm{ATP}$ and $\mathrm{Cl}^{-}$currents, which may have resulted in depolarization and thus caused calcium entry and promoted glucagon secretion. The results of the present study may represent a promising approach for therapeutic applications. In the future, it will be helpful to modulate glucagon secretion to improve diabetic complications in patients.

\section{References}

1. MacDonald PE, De Marinis YZ, Ramracheya R, Salehi A, Ma X, Johnson PR, Cox R, Eliasson L and Rorsman P: A K+ATP channel-dependent pathway within alpha cells regulates glucagon release from both rodent and human islets of Langerhans. PLoS Biol 5: e143, 2007.

2. Vieira E, Salehi A and Gylfe E: Glucose inhibits glucagon secretion by a direct effect on mouse pancreatic alpha cells. Diabetologia 50: 370-379, 2007.

3. Wang Q, Liang X and Wang S: Intra-isle tglucagon secretion and action in the regulation of glucose homeostasis. Front Physiol 3: $485,2013$.

4. Zhou H, Zhang T, Harmon JS, Bryan J and Robertson RP: Zinc, not insulin, regulates the rat alpha-cell response to hypoglycemia in vivo. Diabetes 56: 1107-1112, 2007.

5. Zhou H, Tran PO, Yang S, Zhang T, LeRoy E, Oseid E and Robertson RP: Regulation of alpha-cell function by the beta-cell during hypoglycemia in Wistar rats: The 'switch-off' hypothesis. Diabetes 53: 1482-1487, 2004.

6. Hope KM, Tran PO, Zhou H, Oseid E, Leroy E and Robertson RP: Regulation of alpha-cell function by the $\beta$-cell in isolated human and rat islets deprived of glucose: The 'switch-off' hypothesis. Diabetes 53: 1488-1495, 2004.

7. Okada Y, Taniguchi $\mathrm{H}$ and Schimada C: High concentration of GABA and high glutamate decarboxylase activity in rat pancreatic islets and human insulinoma. Science 194: 620-622, 1976.

8. Briel G, Gylfe E, Hellman B and Neuhoff V: Microdetermination of free amino acids in pancreatic islets isolated from obese-hyperglycemic mice. Acta Physiol Scand 84: 247-253, 1972.

9. Gylfe E and Hellman B: Role of glucose as a regulator and precursor of aminoacidsin the pancreatic beta-cells. Endocrinology 94: 1150-1156, 1974.

10. Hedrington MS, Farmerie S, Ertl AC, Wang Z, Tate DB and Davis SN: Effects of antecedent GABAA activation with alprazolam on counterregulatory responses to hypoglycemia in healthy humans. Diabetes 59: 1074-1081, 2010.
11. Kawai $\mathrm{K}$ and Unger RH: Effects of gamma-aminobutyric acid on insulin, glucagon, and somatostatin release from isolated perfused dog pancreas. Endocrinology 113: 111-113, 1983.

12. Minuk GY and Sarjeant EJ: Insulin and glucagon secretion by the dog pancreas during intravenous and oral administration of gamma aminobutyric acid (GABA). Horm Metab Res 17: 313-314, 1985.

13. Cavagnini F, Pinto M, Dubini A, Invitti C, Cappelletti G and Polli EE: Effects of gamma aminobutyric acid (GABA) and muscimol on endocrine pancreatic function in man. Metabolism 31: 73-77, 1982.

14. Passariello N, Giugliano D, Torella R, Sgambato S, Coppola L and Frascolla N: A possible role of gamma-aminobutyric acid in the control of the endocrine pancreas. J Clin Endocrinol Metab 54: 1145-1149, 1982.

15. Gilon P, Bertrand G, Loubatières-Mariani MM, Remacle C and Henquin JC: The influence of gamma-aminobutyric acid on hormone release by the mouse and rat endocrine pancreas. Endocrinology 129: 2521-2529, 1991.

16. Franklin I, Gromada J, Gjinovci A, Theander S and Wollheim CB: Beta cell secretory products activate alpha cell ATP-dependent potassium channels to inhibit glucagon release. Diabetes 54: 1808-1815, 2005.

17. Mehanna AS: Insulin and oral antidiabetic agents. Am J Pharmaceutical Ed 69: 1-11, 2005.

18. Samols E, Tyler J and Marks V: Glucagon-insulin interrelationships. Pergamon Press, Elmsford, NY, pp151-174, 1972.

19. Maruyama H, Hisatomi A, Orci L, Orci L, Grodsky GM and Unger RH: Insulin within islets is a physiologic glucagon release inhibitor. J Clin Invest 74: 2296-2299, 1984.

20. Raju B and Cryer PE: Loss of the decrement in intraislet insulin plausibly explains loss of the glucagon response to hypoglycemia in insulin-deficient diabetes: Documentation of the intraislet insulin hypothesis in humans. Diabetes 54: 757-764, 2005.

21. Xu E, Kumar M, Zhang Y, Ju W, Obata T, Zhang N, Liu S, Wendt A, Deng S, Ebina Y, et al: Intra-islet insulin suppresses glucagon release via GABA-GABAA receptor system. Cell Metab 3: 47-58, 2006.

22. Rorsman P, Berggren PO, Bokvist K, Ericson H, Möhler H, Ostenson CG and Smith PA: Glucose-inhibition of glucagon secretion involves activation of GABAA-receptor chloride channels. Nature 341: 233-236, 1989.

23. Göpel S, Zhang Q, Eliasson L, Ma XS, Galvanovskis J, Kanno T, Salehi A and Rorsman P: Capacitance measurements of exocytosisin mouse pancreatic alpha-, beta- and delta-cells within intact islets of Langerhans. J Physiol 556: 711-726, 2004.

24. Göpel SO, Kanno T, Barg S, Weng XG, Gromada J and Rorsman P: Regulation of glucagon release in mouse $\alpha$-cells by KATP channels and inactivation of TTX-sensitive Na+channels. J Physiol 528: 509-520, 2000.

25. Slucca M, Harmon JS, Oseid EA, Bryan J and Robertson RP: ATP-sensitive $\mathrm{K}+$ channel mediates the zinc switch-off signal for glucagon response during glucose deprivation. Diabetes 59: $128-134,2010$. 